\title{
Stock performance of Jakarta Islamic Index based on sharpe, Treynor and Jensen method
}

\author{
Edi Susilo*, Ainun Najah \\ Prodi Ekonomi Islam, Fakultas Ekonomi dan Bisnis, UNISNU Jepara, Indonesia \\ *corresponding Author: edisusilo@unisnu.ac.id
}

\section{Keywords:}

Stock Performance, JII, Sharpe, Treynor and Jensen.

DOI: 10.20885/JEKI.vol4.iss2.art2

\begin{abstract}
This study aims to analyse stock performance using the Sharpe, Treynor and Jensen methods at Jakarta Islamic Index during 2014-2016. This research is a descriptive and quantitative research. The object of the research is the stocks listed on Jakarta Islamic Index in the period of 2014 to 2016. The sample selection is determined by purposive sampling technique with the criteria of stocks consistently listed on Jakarta Islamic Index during 2014-2016. By this criteria, this study used 19 stocks as a sample. The result shows that there is no stock that consistently performed positively or consistently outperformed Jakarta Islamic Index against market benchmark.
\end{abstract}

\begin{abstract}
Abstrak
Penelitian ini bertujuan untuk menganalisis kinerja saham dengan menggunakan metode Sharpe, Treynor dan Jensen pada Jakarta Islamic index selama 2014 sampai 2016. Penelitian ini merupakan penelitian kuantitatif deskriptif. Objek penelitian adalah seluruh saham yang terdaftar di Jakarta Islamic index pada periode 2014 sampai 2016. Pemilihan sampel ditentukan dengan teknik purposive sampling dengan kriteria saham yang dijadikan sampel adalah saham syariah dan konsisten tercatat tetap selama periode 2014 sampai 2016, sehingga diperoleh sampel sebanyak 19 saham. Hasil penelitian menunjukkan bahwa tidak ada saham yang konsisten berkinerja positif maupun konsisten outperform di Jakarta Islamic Index terhadap benchmark pasar.
\end{abstract}

\section{Background}

The capital market in Indonesia has recorded significant developments, as evidenced by the increasing number of stocks listed on the capital market (Indonesia Stock Exchange). Since the government reactivated the capital market on August 10, 1977, the role of capital market for corporate funding and investment facilities was getting bigger. The growth of capital market in Indonesia reached its peak since the privatization era of the stock exchange on July 13, 1992 (Nasution, 2015). In the beginning of 2018, the capital market experienced a good increase.

The purpose of investing is to earn returns as expected (Prabowo, 2013), thus it requires an analysis of return and risk will be faced by investors. The greater the risk of an investment, the greater the chance of getting return (high risk high return). Therefore, investors must be able to estimate how much risk they must bear. In terms of minimizing existing risks, investors must invest in various types of stocks to form a portfolio. (Husnan, 2005).

Portfolios can be interpreted as a series of combinations of assets that are invested and held by investors, either individually or institutionally. While portfolio performance evaluation aims to assess the performance of portfolios that have been formed in accordance with investment objectives (Syulviya \& et al, 2015). There are many factors need to be considered in investing in stocks, especially how to choose the good stocks. A good stock can benefit investors in the future. This needs to be carefully considered for investors, especially for new investors. (Nafik, 2009).

One of the stock index that records Islamic stocks on the IDX is Jakarta Islamic Index or abbreviated as JII. It is one of the stock indices in Indonesia that calculates the average stock price index that meets the criteria of Sharia principles (Kurniawan \& Asandimitra, 2014). The rules in Jakarta Islamic Index are regulated in Fatwa DSN-MUI No. 80 concerning the application of Sharia principles in the mechanism of trading of equity securities in the regular market of the stock exchange. Jakarta Islamic Index can be a guide for investors who want to invest their funds in Sharia without fear of being mixed up with usury funds. In addition, JII will become a performance benchmark for halal stock portfolio. (Huda \& Nasution. 2007; Umam, 2013; Sudarsono, 2013).

Amalia \& Kartikasari (2016) stated that the performance of Sharia stock on conventional stock indices shows a positive trend, in which the performance of Islamic stock index slightly exceeded the performance of its counterpart. Therefore investing in Islamic stock is better than conventional one. From Jakarta Islamic Index, there are 30 stocks that are always been revised every 6-month and obtained 19 stocks which are consistently listed on Indonesia Stock Exchange during 2014 to 2016. 
An investment plan needs to be carefully analyzed. Investment analysis is a study of whether or not a project can be successfully implemented. There is a performance analysis of the stock or portfolio itself which aims to find out whether the portfolio is able to improve the achievement of the investment objective or not. Therefore, potential investor can figure out which portfolio has the best performance considering the rate of return and risk. Investors should have a benchmark in investing. Measurement standards are carried out to find out stocks into positive or outperform categories. Positive-performing stocks are stocks that are worth investing in. Whereas stocks that are under-performed are stocks that show negative result and considered in-feasible to invest in (Safitri, Ervita; et al, 2013).

Based on the capital market theory, stock performance can be measured by Sharpe, Jensen and Treynor indices. The three performance measures assume a linear relationship between portfolio returns with returns from several market indices. Thus, stock performance analysis is expected to help investors in making business decisions in determining portfolio in Jakarta Islamic Index.

Dictionary of Economic Law defines stocks as a meeting place for sellers and buyers who trade longterm securities, such as stocks and bonds (Nasution, 2015). Law Number 8 of 1995 Article 1 Number 13 explains that capital market is activity related to public offerings and securities trading, public companies related to the securities issued, also institutions and professions related to securities. Whereas Islamic stock is a proof of capital ownership with the right to share profit which does not contradict with Sharia principles, this concept is called Musharakah or Syirkah activity (Nurhaida \& Kartikasasi, 2016).

Portfolio performance is not only about the level of return generated, but also other factors such as risk, etc. Based on the capital market theory, several measures of portfolio performance have included factors of return and risk in the calculation (Kurniawan \& Asandimitra, 2014). Some measures of portfolio performance (Risk Adjusted Performance) have included return and risk factors into methods of Sharpe Index, Treynor Index, and Jensen Index (Tandelilin, 2010).

\section{Research Methodology}

This study uses a descriptive quantitative approach, with secondary data as the data source. Secondary data is data that is already available (using material which is not from the first source), thus we only need to search and collect information for the problems to be examined (Sarwono, 2006). While descriptive research is a study that aims to provide or describe a situation or phenomenon that occurs at this time by using a scientific procedure to answer the actual problem (Sarwono, 2006). Data collection is done through: www.idx.co.id website in the form of monthly data from 2014 to 2016 and taken at the closing price.

Table 1. List of Stocks Listed in JII consistently during 3 Years (2014-2016)

\begin{tabular}{ccl}
\hline No. & Issuer Code & Name of Stocks \\
\hline 1 & AALI & Astra Argo Lestari Tbk (s) \\
2 & ADRO & Adaro Energy Tbk (s) \\
3 & AKRA & AKR Corporindo Tbk (s) \\
4 & ASII & Astra International Tbk (s) \\
5 & ASRI & Alam Sutera Realty Tbk (s) \\
6 & BSDE & Bumi Serpong Damai Tbk (s) \\
7 & ICBP & Indofood CBP Sukses Makmur Tbk (s) \\
8 & INDF & Indofood Sukses Makmur Tbk (s) \\
9 & INTP & Indocement Tunggal Prakasa Tbk (s) \\
10 & KLBF & Kalbe Farma Tbk (s) \\
11 & LPKR & Lippo Karawaci Tbk (s) \\
12 & LSIP & PP London Sumatra Indonesia Tbk (s) \\
13 & PGAS & Perusahaan Gas Negara (Persero) Tbk (s) \\
14 & SMGR & Semen Indonesia (Persero) Tbk (s) \\
15 & SMRA & Summarecon Agung Tbk (s) \\
16 & TLKM & Telekomunikasi Indonesia (Persero) Tbk (s) \\
17 & UNTR & United Tractors Tbk (s) \\
18 & UNVR & Unilever Indonesia Tbk (s) \\
19 & WIKA & Wijaya Karya (Persero) Tbk (s) \\
\hline Source: Data processed &
\end{tabular}

This study uses stock data that are consistently listed in Jakarta Islamic Index and take benchmark of Jakarta Islamic Index as a comparison. It also uses BI rate starting from 2014 to 2016, the data is obtained as raw data. Standard benchmark of BI 7-day Reserve Repo Rate is used as a standard for beta portfolio of investment measurements, to maintain positive changes in the long term or the fastest in the next few months for general 
economic stability. Then the raw data is processed and explained descriptively so that it can produce information that is useful for investment players, especially potential investors.

Here is the description of the data during the observation period. There are 40 stocks in and out in total. The purposive sampling technique in this study is used with several criteria, so that the samples are made in accordance with the research objectives. Criteria based on selection for consistently listed on IDX during three years, from 2014 to 2016, then resulted in 19 stocks. List of issuers is seen in the Table 1.

Measurement of stock performance in this study was using Sharpe, Treynor and Jensen method. The Sharpe method measures market performance by dividing excess returns to standard deviation returns, Treynor method measures market performance by dividing excess returns with market risk or systematic risk, and Jensen method adds the average of past returns with required return. Further, the classification is made between positive portfolio (those stated outperform) and negative one (those stated underperform). The three methods above assume that the higher the value, the better the performance of a stock. Stocks that have a positive value are those which are worth buying or including in an investment portfolio according to all three models.

\section{Calculation Steps}

The first step to calculate the Average Monthly Return of the Stock Portfolio is by using Closing Price that has been published on the website www.idx.co.id to the formula below (Samsul, 2006):

$R_{i t}=\frac{P_{\mathrm{t}}-P_{\mathrm{t}-1}}{P_{\mathrm{t}-1}}$

where : $R_{i t}$ is actual return for stock $i$ on $k$ day/month $t ; P_{\mathrm{t}}$ is stock price at $t$ and $P_{\mathrm{t}-1}$ is stock price at $k(\mathrm{t}-1)$

The second step is to calculate the average monthly return of stock. The average return is obtained by dividing the total return during the observation period by the number of observation periods. To simplify the calculation in this study, the following formula is used (Samsul, 2006):

$\overline{R_{p}}=\sum \frac{R_{i t}}{n}$

where $\overline{R_{p}}$ is average monthly return of portfolio stock; $R_{i t}$ is total return on observation period; and, $n$ is Number of observation period

Next, calculate the Average Market Return of JII. The average monthly market return index of JII can be used to calculate market returns so that it can be showthe rate of return on profits obtained by the market. The average monthly index is obtained from the site www.idx.co.id

The first step to calculate the Market Return is using this formula (Samsul, 2006):

$R_{m}=\frac{J I I_{t}-J I I_{t-1}}{J I I_{t-1}}$

where, $R_{m}$ is market return; $J I I_{t}$ is JII Index for this month; and, $J I I_{t-1}$ is JII Index for previous month

The second step is to calculate the average return of JII, the average return can be obtained by dividing the total return during the observation period with the number of observation periods (Samsul, 2006). The formula used is as follows:

$\overline{\mathrm{R}_{\mathrm{m}}}=\frac{\sum \mathrm{R}_{\mathrm{m}}}{\mathrm{n}}$

where, $\overline{R_{m}}$ is average monthly return of JII; $\sum R_{m}$ is total return on observation period, and $n$ is number of observation period

The next step is to calculate the Average Monthly Return for SBI; SBI or BI Rate set by Bank Indonesia. In this study, they will function as a risk-free rate. The monthly average BI rate is obtained in the following calculations (Samsul, 2006):

$\overline{R_{f}}=\sum \frac{R_{f i}}{n}$

where, $\overline{R_{f}}$ is risk free retur, $R_{f i}$ is total return on observation period, and $n$ is number of observation period 
Performance Calculation Using Sharpe Method. Standard deviation is a variable that must be given before calculating stock performance with Sharpe method. Standard deviation calculations can be through Microsoft Excel program or the following formula (Samsul, 2006):

SDpi $=\sqrt{\frac{\sum\left(\mathrm{R}_{\mathrm{i}} \cdot \overline{\mathrm{R}_{1}}\right)^{2}}{(\mathrm{n}-1)}}$

$\overline{\mathrm{X}}=\frac{\sum \mathrm{X}}{\mathrm{n}}$

where, $S D(\sigma) p i$ is sample standard deviation; $R i$ is return on certain sample; $\bar{X}$ is average sample count; $n$ is number of observation data, and; $\sum \mathrm{X}$ is total of all $\mathrm{X}$ (data) from sample

After knowing the standard deviation, we need to calculate the performance with Sharpe method using the following formula (Tandelilin, 2010):

$S_{p}=\frac{\overline{R_{p}}-\overline{R_{f}}}{S D_{T R}}$

where: $S_{p}$ is index of sharpe portfolio; $\overline{R_{p}}$ is average return of portfolio $p$ during 2014-2016; $\overline{R_{f}}$ is Average return of risk-free during 2014-2016; and, $S D_{T R}$ is standard deviation of portfolio return during 2014-2016

Calculation of Performance with Treynor Method. Beta is a variable that must be available before calculating stock performance with Treynor method. Beta $(\beta)$ can be calculated by the following formula (Samsul, 2006):

$\beta_{p}=\frac{\sigma_{i m}}{\sigma_{m}^{2}}=\frac{\sum\left|\left(R_{i}-\overline{R_{l}}\right)\left(R_{m}-\overline{R_{m}}\right)\right|}{\sum\left(R_{m}-\overline{R_{m}}\right)^{2}}=\frac{\operatorname{Covar}(R p, R m)}{\text { market variance }}$

where, $\beta_{p}$ is risk of individual beta; $\sigma_{i m}$ is covariance between portfolio and market return; and, $\sigma_{m}^{2}$ is market variance

After knowing Beta $(\beta)$, we need to calculate the stock performance with Treynor method using the following formula (Tandelilin, 2010):

$T_{p}=\frac{\overline{R_{p}}-\overline{R_{f}}}{\beta_{p}}$

where, $T_{p}$ is index of Treynor portfolio; $\overline{R_{p}}$ is average return of stock portfolio during $2014-2016$; $\overline{R_{f}}$ is average return of risk-free during 2014-2016, and $\beta_{p}$ is beta of stock portfolio

Performance Calculation with Jensen Method. Variables that must be given before calculating Jensen method are as same as what Treynor requires; beta value. The formula for Jensen method is, as follows:

Metode Jensen $=\left(\overline{R_{p}}-\overline{R_{f}}\right)-\left(R_{m}-\overline{R_{f}}\right) \beta_{p}$

where, $J_{p}$ is index of Jensen portofolio; $\overline{R_{p}}$ is average return of stock portofolio during 2014-2016; $\overline{R_{f}}$ is average return of risk-free during 2014-2016; $R_{m}$ is market return; and, $\beta_{p}$ is beta of stock portofolio

\section{Result and Discussion}

The monthly closing price data is known at the end of each month. JII and BI rates starting from January 2014 to 2016 as raw data is then processed and explained descriptively so that it can produce information that is useful for investment players, especially stock investors who use JII.

The following is the description of the data during the study period of average monthly return of 19 shares, JII and SBI rate in 2014: 


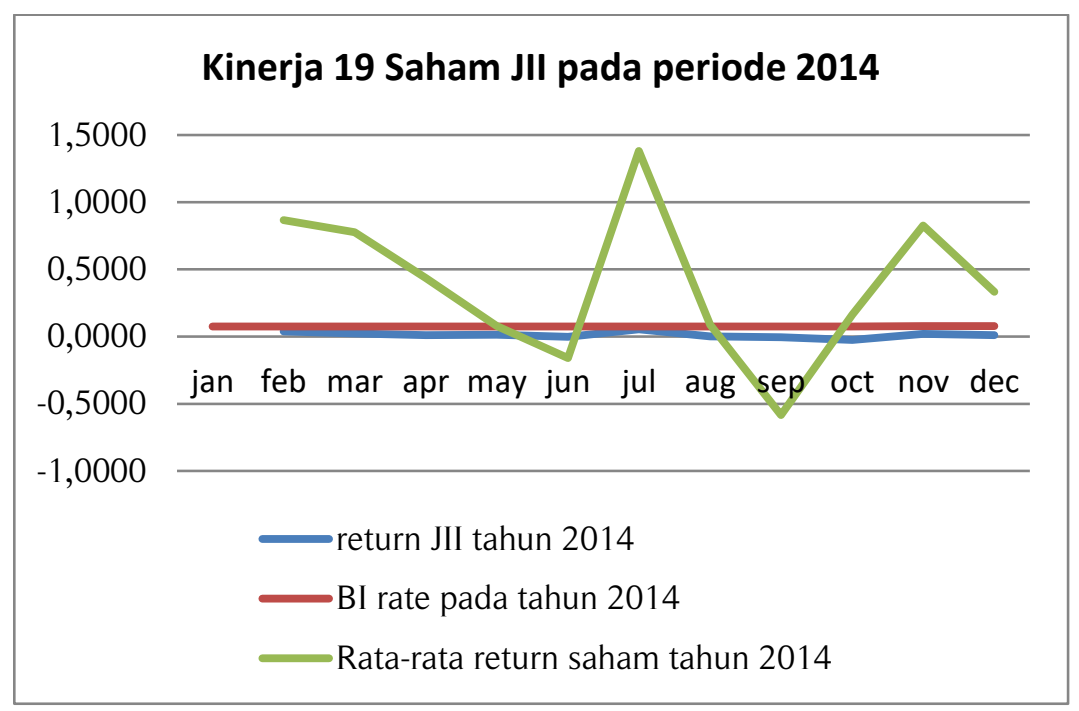

Graph 1. Average Performance of 19 Stocks, JII and BI rate in 2014

Based on Graph 1, it can be seen that at the beginning to the end of 2014 the average performance of 19 shares and JII was below BI rate performance, while at the end of March the performance of 19 shares and JII began to decline. A fluctuating decline occurred in March, April, May, and early June. At the beginning of June until the end of July it experienced a sharp increase to get closer with BI rate. However, in late July to September, it experienced a sharp decline. At the beginning of August until the beginning of November it increased again. At the end of November to the end of December, there was a decline.

The following is the description of the data during the study period of average monthly return of 19 shares, JII and SBI rate in 2015:

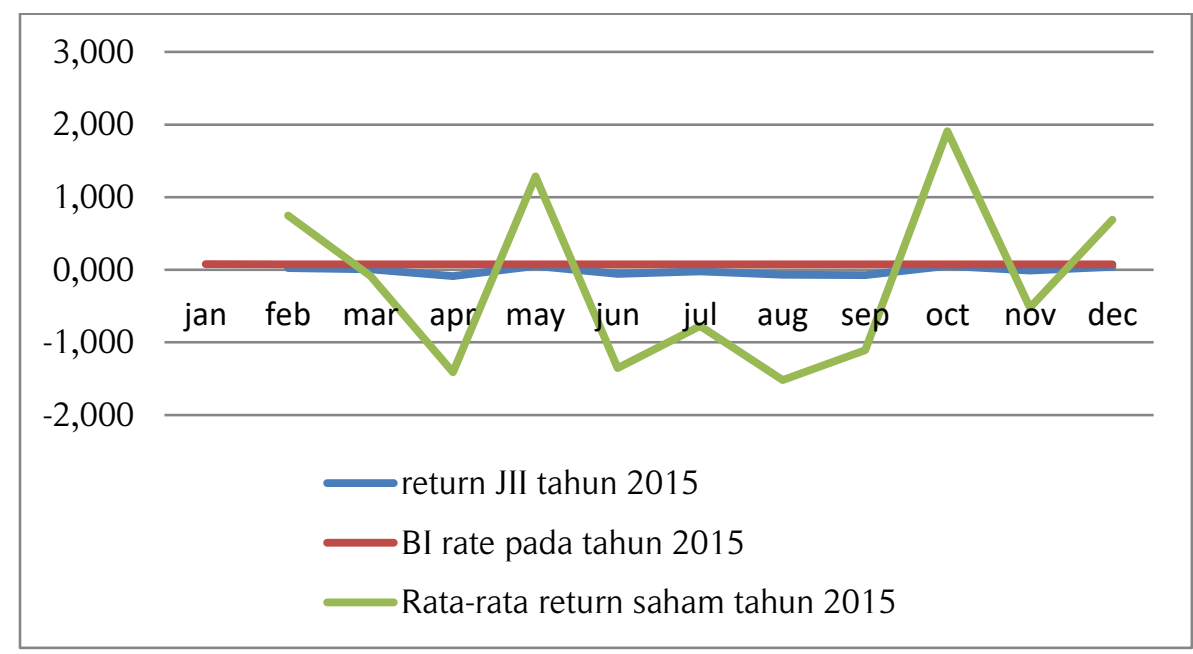

Graph 2. Average Performance of 19 Stock, JII and BI rate in 2015

Based on graph 2, it can be seen that at the beginning to the end of 2015 the average performance of 19 stocks was fluctuating, and the performance of the JII index was below that of BI Rate. In the beginning of January until the end of March the average stock return declined sharply. However, in May it rose sharply and after that it dropped sharply. FromJune to September the movement of stock price fluctuated and when it headed for October the movement increased sharply. Whereas in November there was a sharp decline. At the end of November to the end of December, there was an increase.

The following is the description of the data during the study period of average monthly return of 19 shares, JII and SBI rate in 2015: 


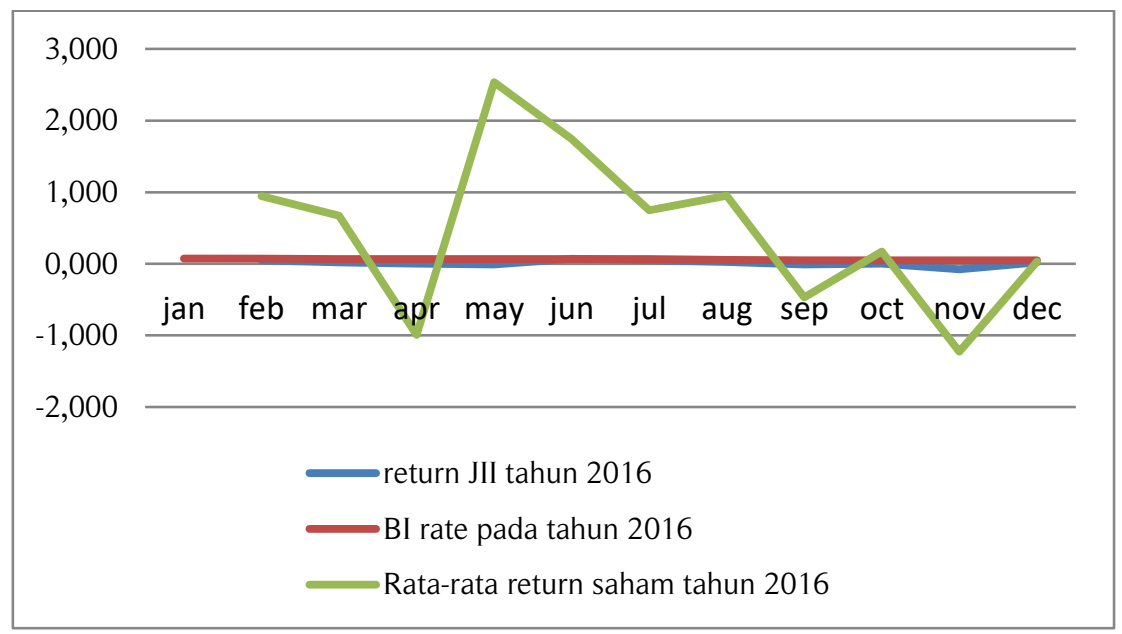

Graph 3. Average Performance of 19 Stocks, JII and BI rate in 2016

Based on graph 3, it can be seen that at the beginning to the end of 2016 the average performance of 19 stocks was fluctuating, and the performance of JII index was parallel to that of BI Rate. In early February until the end of April the average stock return declined. However, at the beginning of May it rose sharply and after that until the beginning of November it declined. At the end of November to the end of December, there was an increase. Since the performance of 19 stocks in 2014, 2015 and 2016 is still fluctuating, it still needs to be considered to invest in stocks listed on JII.

\section{Stock Performance in 2014 Using Sharpe Method}

Calculation of the sharpe index in 2014 shows that the highest portfolio performance is Wijaya Karya Tbk. (WIKA) with a value of -0.1157 . While the lowest performance is Indofood Sukses Makmur Tbk (s) (INDF) with a value of $-2,616$. However, on average the value is equal to -1.1410 . Negative mean values indicate that portfolio performance is considered bad. In this case if the sharpe/RVAR performance index value is positive and getting bigger then the portfolio performance is getting better. Whereas if the sharpe/RVAR performance index value is negative and getting smaller, the portfolio performance is getting worse.

From the analysis results, 19 consistent stocks listed on Jakarta Islamic Index in 2014 using Sharpe method as a performance measurement are considered not feasible to be chosen because there was no outperform of the market sharpe index and values obtained are negative.

\section{Stock Performance in 2015 Using Sharpe Method}

The calculation of the sharpe index in 2015 shows that the highest portfolio performance is Summarecon Agung Tbk (s) (SMRA) with a value of -0.4151 . While the lowest performance is the stock of Kalbe Farma Tbk (s) (KLBF) with a value of -1.5553 . However, on average the value is equal to -0.9850 . Negative mean values indicate that portfolio performance is considered bad. In this case if the sharpe/RVAR performance index value is positive and getting bigger then the portfolio performance is getting better. Whereas if the sharpe/RVAR performance index value is negative and getting smaller, the portfolio performance is getting worse.

From the analysis results, 19 consistent stocks listed on Jakarta Islamic Index in 2015 using Sharpe method as a performance measurement are considered not feasible to be chosen because there was no outperform of the market sharpe index and values obtained are negative.

\section{Stock Performance in 2016 Using Sharpe Method}

The calculation of Sharpe index in 2016 shows that the highest portfolio performance is Adaro Energy Tbk (s) (ADRO) with a value of 0.5391 . Whereas the lowest performance is Indocement Tunggal Prakasa Tbk (s) (INTP) with a value of -1.5643 . However, on average the value is equal to -0.5628 .

From the analysis results of 19 consistent stocks listed on Jakarta Islamic Index in 2016 using Sharpe method as a performance gauge, only 2 stocks are eligible to be chosen and the rest is not feasible due to negative performance. The best stock performance which show positive value and outperform the benchmark are Adaro Energy Tbk (s) (ADRO) and AKR Corporindo Tbk (s) (AKRA) with value of 0.5391 and 0.1438. 


\section{Stock Performance in 2014 Using Treynor Method}

Based on the result of performance calculation with Treynor method, there is 1 stock with a positive value and 18 other negative stocks, meaning that only 1 stock performed well in 2014.

From the analysis results of 19 consistent stocks listed on Jakarta Islamic Index in 2014 using Treynor method as a performance gauge, only 1 stock is eligible to be chosen and the rest is not feasible due to negative performance. The best stock performance which show positive value and outperform the benchmark are London Sumatra Indonesia Tbk (s) PP shares (LSIP) with a value of 0.0705 .

\section{Stock Performance in 2015 Using Treynor Method}

The calculation of Treynor index in 2015 shows that the highest portfolio performance is Summarecon Agung Tbk (s) (SMRA) stock with a value of -0.0309. Whereas the lowest performance is Unilever Indonesia Tbk (s) (UNVR) with a value of -0.5945 . However, on average the value is equal to -0.1147 . Negative mean values indicate that portfolio performance is considered bad.

Based on the results of the comparison of stock performance with the benchmark of Treynor Market Index in 2015, there are 10 stocks which indicate that investing in 10 stocks is less risky than investing in the market of Treynor index. Therefore, there is no stock worth investing because they have negative values and underperform the performance benchmark.

From the analysis results, 19 consistent stocks listed on Jakarta Islamic Index in 2015 using Treynor method as a performance measurement are considered not feasible to be chosen because there was no outperform of the market sharpe index and values obtained are negative.

\section{Stock Performance in 2016 Using Treynor Method}

The calculation of Treynor index in 2016 shows that the highest portfolio performance is Indofood CBP Sukses Makmur Tbk (s) (ICPB) with a value of 1.4530. Whereas the lowest performance is Indocement Tunggal Prakasa Tbk (s) (INTP) with a value of -0.1420 . However, on average the value is equal to 0.0621 . Positive average values indicate that portfolio performance is considered good. In this case, if Treynor/RVOL performance index value is positive and getting bigger, the portfolio performance is getting better.

From the analysis results of 19 consistent stocks listed on Jakarta Islamic Index in 2016 using Treynor method as a performance measurement, only 4 stocks are eligible to be chosen and the rest is not feasible due to negative performance. The best stock performance which show positive value and outperform the benchmark are Indofood CBP Sukses Makmur Tbk (s) (ICPB), Astra Argo Lestari Tbk (s) (AALI), London Sumatra Indonesia Tbk (s) (LSIP) and Adaro Energy Tbk (s) (ADRO) with value of 1.4530, 0.4444, 0.0454 and 0.0352.

\section{Stock Performance in 2014 Using Jensen Method}

The calculation of Jensen index in 2014 shows that the highest performing portfolio is the Alam Sutera Realty Tbk (s) (ASRI) share with a value of 0.1558. While the lowest performance is London Sumatra Indonesia Tbk (s) PP (LSIP) with a value of -0.1725 . However, on average the value is equal to 0.0056 . Positive average values indicate that portfolio performance is considered good.

From the analysis results of 19 consistent stocks listed on Jakarta Islamic Index in 2014 using Jensen method as a performance measurement, only 8 stocks are eligible to be chosen and the rest is not feasible due to negative performance. The best stock performance which show positive value and outperform the benchmark are ASRI, SMRA, WIKA, ASII, BSDE, LPKR, SMGR and TLKM with values of 0.1558, 0.1314, 0.1215, 0.0464, $0.0289,0.0182,0.0165$ and 0.0098 .

\section{Stock Performance in 2015 Using Jensen Method}

The calculation of Jensen index in 2015 shows that the highest performance portfolio is the Summarecon Agung Tbk (s) (SMRA) share with a value of 0.1180. While the lowest performance is Adaro Energy Tbk (s) (ADRO) shares with a value of -0.0652 . However, on average the value is equal to 0.0081 . Positive average values indicate that portfolio performance is considered good.

From the analysis results of 19 consistent stocks listed on Jakarta Islamic Index in 2015 using Jensen method as a performance measurement, only 2 stocks are eligible to be chosen and the rest is not feasible due to negative performance. The best stock performance which show positive value and outperform the benchmark are Summarecon Agung Tbk (s) (SMRA) and Bumi Serpong Damai Tbk (s) (BSDE) with values of 0.1180 and 0.0665. 


\section{Stock Performance in 2016 Using Jensen Method}

The calculation of Jensen index in 2016 shows that the highest portfolio performance is Adaro Energy Tbk (s) (ADRO) with a value of 0.1340 . While the lowest performance is Indofood CBP Sukses Makmur Tbk (s) (ICPB) with a value of -0.0908 . However, on average the value is equal to 0.0010 . Positive average values indicate that portfolio performance is considered good. In this case if the ALPHA performance index value is positive and getting bigger, the portfolio's performance will be better. Whereas if the ALPHA performance index value is negative and getting smaller, the portfolio performance will be worse.

From the analysis results of 19 consistent stocks listed on Jakarta Islamic Index in 2016 using Jensen method as a performance measurement, only 5 stocks are eligible to be chosen and the rest is not feasible due to negative performance. The best stock performance which show positive value and outperform the benchmark are ADRO, ASRI, INDF BSDE and ASII with values of 0.1340, 0.0612, 0.0520, 0.0332 and 0.0292.

\section{Conclusion}

Based on the analysis during 2014-2016 using Sharpe, Treynor and Jensen method simultaneously, it shows that there is no consistent stock listed on Jakarta Islamic Index having positive performance and outperforming the market benchmark. However, when analysed particularly by Jensen method, there is only one stock that is worth investing, namely Bumi Serpong Damai Tbk (s) (BSDE). The result of the performance of Jakarta Islamic Index using Sharpe method shows positive values, namely Adaro Energy Tbk (s) 's shares (ADRO) and AKR Corporindo Tbk (s) (AKRA). The stock performance using Treynor method shows positive values namely London Sumatra Indonesia Tbk (s) PP (LSIP), Indofood CBP Success Makmur Tbk (s) (ICPB), Astra Argo Lestari Tbk (s) (AALI), and Adaro Energy Tbk (s) (ADRO). While the best stock performance using Jensen method which show positive performance are 18 shares, including ADRO, INDF, BSDE, ASII, KLBF, AKRA, SMRA, UNVR, WIKA, INTP, PGAS, AALI, LSIP, SMGR, TLKM, ICPB, ASRI and LPKR. The stock performance listed on Jakarta Islamic Index which shows positive results during 2014-2016 using all three methods is Adaro Energy Tbk (s) (ADRO) as it performed well and deserved to be picked as an investment choice.

\section{Bibliography}

Amalia, A. D., \& Kartikasari, D. (2016). Analisis Perbandingan Kinerja Saham Perusahaan Manufaktur Terindeks Syariah dan Konvensional. Jurnal Akuntansi, Ekonomi dan Manajemen Bisnis, 4(2), 128-135

Huda, N., \& Nasution, M. E. (2007). Investasi pada Pasar Modal Syariah. Jakarta: Kencana PrenadaMedia Group.

Husnan, S. (2005). Dasar-Dasar Teori Portofolio dan Analisis Sekuritas. Yogyakarta: Unit Penerbit dan Percetakan AMP YKPN.

Kurniawan, R. D., \& Asandimitra, N. (2014). Analisis Perbandingan Kinerja Indeks Saham Syariah dan Kinerja Indeks Saham Konvensional. Jurnal Ilmu Manajemen, 2(4).

Nafik HR, M. (2009). Bursa Efek dan Investasi Syariah. Jakarta: PT Serambi Ilmu Semesta.

Nasution, Y. S. (2015). Peranan Pasar Modal dalam Perekonomian Negara. Human Falah, 2(1), 95-112

Nurhaida, \& Kartikasasi, F. (2016). Sinergi Menuju Pasar Modal Syariah Yang Lebih Besar dan Berkembang. Jakarta: Direktorat Pasar Modal Syariah OJK.

Prabowo, H. (2013). Analisis Portofolio Saham Dengan Metode CAPM dan Markowitz. Binus Business Review, 4(1). 360-369

Safitri, E, Nilawati, A, \& Widyastuty, P (2013). Perbedaan Kinerja Saham Pada Perusahaan Agriculture Sebelum dan Sesudah dan Pada Saat Krisis Ekonomi Global di BEI. Forum Bisnis Dan Kewirausahaan Jurnal Ilmiah STIE MDP, 3(1), 26-36

Samsul, M. (2006). Pasar Modal dan Manajemen Portofolio. Surabaya: Airlangga.

Sarwono, J. (2006). Metode Penelitian Kuantitatif dan Kualitatif. Yogyakarta: Graha Ilmu.

Sudarsono, H (2013). Bank dan Lembaga Keuangan Syariah : Deskripsi dan Ilustrasi, Yogyakarta : Ekonisia.

Syulviya, S. A., Handayani, S.R \& Hidayat, R. (2015). Evaluasi Kinerja Investasi Portofolio dengan Menggunakan Model Treynor (Studi pada Perusahaan Food \& Beverages yang Listing di BEI Periode 2013). Jurnal Administrasi Bisnis (JAB)|, 23(1), 1-10

Tandelilin, E. (2010). Portofolio dan Investasi (Teori dan aplikasi) Edisi pertama. Yogyakarta: Kanisius

Umam, K. (2013). Pasar Modal Syariah \& Pratik Pasar Modal Syariah. Bandung: CV Pustaka Setia. 